\title{
Pengaruh Latihan Konsep Diri Terhadap Peningkatan Kemandirian Belajar Peserta Didik Di MAN 1 Polewali Kabupaten Polewali Mandar
}

\author{
Muji Rahayu \\ Institut Agama Islam DDI Polewali Mandar \\ Jl. Gatot Soebroto Kelurahan Madatte Kecamatan Polewali Kab. Polewali Mandar
}

\begin{abstract}
ABSTRAK
Penelitian ini bertujuan untuk mengetahui pengaruh latihan konsep diri terhadap peningkatan kemandirian belajar peserta didik di MAN 1 Polewali Kabupaten Polewali Mandar. Penelitian ini merupakan penelitian explanatory research dengan tipe ekspos fakto. Pendekatan yang digunakan adalah pendekatan kuantitatif. Populasi penelitian ini adalah semua peserta didik di MAN 1 Polewali Kabupaten Polewali Mandar sebanyak 1152 orang dengan jimlah sampel 37 responden peserta didik yang ditentukan secara probability sampling dengan teknik pengambilan simple random sampling. Metode pengumpulan data yang digunakan adalah observasi, kuesioner, studi pustaka dan telaah dokumen. Data-data yang telah dikumpulkan dianalisis dengan teknik analisis statistik deskriptif dan analisis statistik inferensial menggunakan analisis regresi linear sederhana.

Hasil penelitian menunjukkan bahwa latihan konsep diri berpengaruh positif dan signifikan terhadap peningkatan kemandirian belajar peserta didik di MAN 1 Polewali Kabupaten Polewali Mandar. Hal tersebut berarti bahwa semakin sering peserta didik latihan konsep diri, maka kemandirian belajar peserta didik tersebut akan semakin meningkat pula. Hal ini terbukti dari skor pencapaian konsep diri peserta didik yang berada dalam kategori sedang, maka hal tersebut diikuti pula dengan skor pencapaian kemandirian belajar peserta didik yang juga berada dalam kategori sedang. Besar korelasinya adalah 0,641 yang berkategori sedang dan nilai signifikansi lebih kecil dari 0,05 yaitu $0,000<0,05$. Kontribusi pengaruh variabel latihan konsep diri terhadap peningkatan kemandirian belajar peserta didik di MAN 1 Polewali Kabupaten Polewali Mandar sebesar 41,1\%, sedangkan sisanya yaitu 58,9\% dipengaruhi oleh faktor lain di luar bahasan penelitian.
\end{abstract}

Kata Kunci: Latihan Konsep Diri dan Kemandirian Belajar

\section{PENDAHULUAN}

\section{A. Latar Belakang Masalah}

Pendidikan merupakan proses yang terjadi dalam kehidupan manusia dan mengakibatkan perubahan pada individu. Perubahan tersebut akibat dari pengalaman berinteraksi dengan lingkungan sejak lahir sampai meninggal. Pendidikan adalah segala situasi hidup yang mempengaruhi pertumbuhan individu sebagai pengalaman belajar yang berlangsung dalam segala lingkungan dan sepanjang hidup. ${ }^{1}$ Pendidikan merupakan penyampaian pengetahuan, nilai, dan kecakapan oleh pendidik kepada peserta didik. Dengan demikian, dalam proses pendidikan tidak hanya pengetahuan atau kecakapan saja yang diajarkan melainkan nilai-nilai karakter. Pendidikan mengenai nilai-nilai

${ }^{1}$ Syaiful Sagala, Konsep dan Makna Pembelajaran (Bandung: Alfabeta, 2010), h. 1. 
tersebut yang dinamakan pendidikan karakter. Penanaman pendidikan karakter di sekolah sangat penting mengingat pada saat ini banyak permasalahan mulai dari tawuran antar pelajar, kegiatan mencontek, kasus bullying, kekerasan di sekolah dan masih banyak lagi. ${ }^{2}$

Selain itu, sekolah berperan sebagai tempat pendidikan moral menjadi penting karena banyak siswa yang mendapatkan sedikit moral dari orang tua mereka dan ketika makna nilai yang berpengaruh yang didapatkan dari tempat ibadah perlahan tidak berati dan menghilang dari kehidupan mereka. Oleh karena itu, di sekolah perlu diadakan pendidikan karakter untuk memberikan pendidikan moral pada siswa. ${ }^{3}$

Pendidikan karakter mempunyai 18 nilai karakter, yaitu: 1) Religius, 2) Jujur, 3) Tolransi, 4) Disiplin, 5) Kerja keras, 6) Kreatif, 7) Mandiri, 8) Demokratis, 9) Rasa ingin tahu, 10) Semangat Kebangsaan, 11) Cinta Tanah Air, 12) Menghargai prestaasi, 13) Bersahabat, 14) Cinta damai, 15) Gemar membaca, 16) Peduli lingkungan, 17) Peduli sosial, dan 18) Tanggung jawab. Kemandirian sebagai salah satu dari 18 nilai karakter tersebut adalah tidak menggantungkan diri kepada orang lain dan berusaha dengan kemampuannya sendiri. ${ }^{4}$ Kemandirian seperti ini diperlukan dalam kegiatan belajar. Kemandirian belajar diberikan kepada siswa agar siswa mempunyai tanggung jawab dan mendisiplinkan dirinya serta mengembangkan kemampuan belajar atas kemauan sendiri.

Untuk mewujudkan berkembangan pengetahuan, pemahaman, dan kemampuan analisis siswa terhadap kondisi sosial masyarakat, siswa terlebih dahulu harus memahami dirinya dan memiliki keyakinan pada dirinya sendiri yang kemudian akan menentukan siapa siswa tersebut menurut pemikirannya yang berpengaruh pada perilakunya. Hal tersebut dapat diperoleh melalui pemahaman tentang konsep diri yang baik.

Konsep diri merupakan suatu keadaan seseorang memiliki sikap yang positif terhadap diri sendiri, mengakui, dan menerima berbagai aspek diri termasuk kualitas baik dan buruk yang ada pada diri dan memandang positif terhadap kehidupan yang telah dijalani. ${ }^{5}$ Konsep diri akan berpengaruh positif atau negatif dalam mengembangkan sikap, berpengaruh positif atau negatif terhadap dirinya sendiri dan lingkungan yang dihadapinya. Konsep diri merujuk pada bagaimana individu memahami dirinya sebagai pribadi dalam upaya mengoptimalkan potensinya.

Layanan bimbingan dan konseling yang terdapat di sekolah memiliki peranan yang penting dalam pengembangan peserta didik, khususnya konsep diri peserta didik. Sesuai dengan fungsi bimbingan dan konseling yaitu pemahaman, pencegahan, pengentasan, pemeliharaan dan pengembangan. Konsep diri sangat penting untuk seseorang karena dengan adanya konsep diri maka seseorang dapat mengontrol perilakunya, dapat mengetahui mana yang baik dan buruk baginya. Adapun masalah konsep diri peserta didik dapat dikategorikan masalah pribadi sosial, karena peserta didik yang memiliki konsep diri negatif tidak hanya berpengaruh buruk terhadap perkembangan dirinya, akan tetapi juga berpengaruh bagaimana ia berinteraksi terhadap situasi dilingkungannya.

\footnotetext{
${ }^{2}$ Tatang M. Amirin, Manajemen Pendidikan (Yogyakarta: UNY Press, 2011), h. 2.

${ }^{3}$ Thomas Lickona, Educating For Character: Mendidik untuk Membentuk Karakter: Bagaimana Sekolah dapat Memberikan Pendidikan tentang Sikap Hormat dan Bertanggung Jawab (Jakarta: Bumi Aksara, 2012), h. 32.

${ }^{4}$ Rusman, Model-model Pembelajaran Mengembangkan Profesional Guru (Jakarta: Rajawali Press, 2011), h. 359.

${ }^{5}$ Ahmad Sutoyo, Pemahaman Individu (Semarang: Widya Karya, 2009), h. 280.
} 
Fungsi layanan konseling kelompok yang di dalamnya menggunakan assertive training adalah mengenai fungsi kuratif atau pengobatan. Konseling kelompok bersifat penyembuhan dalam pengertian membantu individu dapat keluar dari persoalan yang dialaminya dengan cara memberi kesempatan, dorongan, juga pengarahan kepada individu, untuk mengubah sikap dan perilakunya. ${ }^{6}$ Setiap individu pasti memiliki konsep diri, tetapi mereka tidak mengerti apakah konsep diri yang dimiliki itu negatif atau positif. Peserta didik yang memiliki konsep diri positif terlihat lebih optimis, penuh percaya diri, dan selalu bersikap positif terhadap segala sesuatu, juga terhadap kegagalan yang dialaminya.

Peserta didik dengan konsep diri positif akan mampu menghargai dirinya dan melihat hal-hal yang positif yang dapat dilakukan demi keberhasilan di masa yang akan datang. ${ }^{7}$ Konsep diri negatif pada indikatornya memiliki ciri-ciri yakni peka terhadap kritik, responsif terhadap pujian, memiliki sikap hiperkritis, cenderung merasa tidak disukai orang lain dan pesimistis terhadap kompetisi.

Siswa yang memiliki konsep diri positif akan lebih mudah dalam mengembangkan dirinya dibandingkan siswa yang memiliki konsep diri negatif. Semakin baik atau positif konsep diri seseorang, maka akan semakin mudah ia akan mencapai keberhasilan, sebab dengan konsep diri yang baik/positif seseorang yakin akan kemampuan dalam mengatasi masalah, merasa setara dengan orang lain, menerima pujian tanpa rasa malu, menyadari bahwa setiap orang memiliki perasaan dan keinginan serta perilaku yang tidak seharusnya disetujui oleh masyarakat, dan mampu intropeksi diri serta memperbaiki diri. Sebaliknya, semakin jelek atau negatif konsep diri maka akan semakin kecil peluang seseorang untuk berhasil, sebab seseorang akan menolak terhadap kritikan, responsif sekali terhadap pujian, cenderung bersikap hiperkritis yaitu selalu mengeluh, mencela, meremehkan orang lain, mereka tidak pandai dan tidak sanggup mengungkapkan penghargaan atau pengakuan pada kelebihan orang lain, serta bersikap pesimis terhadap kompetisi. Dengan demikian, konsep diri sangat penting dalam proses belajar menuju ke arah belajar mandiri. ${ }^{8}$

Konsep diri tidak dapat terbentuk tanpa melalui proses belajar atau latihan, proses belajar atau latihan ini dapat diperoleh dari interaksi dengan orang lain. Dengan terjadinya interaksi antara individu dengan lingkungan sekitarnya, akan mengembangkan konsep diri individu tersebut baik kearah positif maupun negatif. Masalah dan kegagalan yang dialami peserta didik disebabkan oleh sikap negatif terhadap dirinya sendiri, yaitu menganggap dirinya tidak berarti. Perilaku peserta didik yang menyimpang dari aturan yang berlaku di sekolah disebabkan oleh pandangan negatif terhadap dirinya, yaitu dirinya tidak mampu menyelesaikan tugasnya. Dalam hal ini individu dapat menerima dirinya secara apa adanya dan akan mampu menginstrofeksi diri atau lebih mengenal dirinya melalui kelebihan dan kekurangan yang dimiliki.

Keberhasilan seseorang untuk mandiri adalah harus memiliki konsep diri yang stabil karena konsep diri yang stabil dapat membantu seseorang memandang dirinya dengan cara yang lebih konsisten dan akhirnya dapat meningkatkan kemandirian dan memperkecil rasa ketidakmampuan. ${ }^{9}$

\footnotetext{
${ }^{6}$ Edi Kurnanto, Konseling Kelompok (Bandung: Alfabeta, 2013), h. 9.

${ }^{7}$ Syam W Nina, Psikologi Sosial (Bandung: Remaja Rosdakarya, 2012), h. 56.

${ }^{8}$ Pradipta Sarastika, Buku Pintar Tampil Percaya Diri (Yogyakarta: ARASKA, 2014), h. 70-74.

${ }^{9}$ Elizabeth B. Hurlock, Perkembangan Anak Jilid 2 (Jakarta: Erlangga, 2013), h. 72.
} 
Kemandirian belajar diartikan sebagai aktivitas belajar yang berlangsungnya lebih didorong oleh kemauan dan tanggung jawab sendiri oleh pembelajar. ${ }^{10}$

Kemandirian baik secara langsung maupun tidak langsung dapat memengaruhi kehidupan peserta didik. Secara spesifik, masalah kemandirian menuntut suatu kesiapan individu, baik kesiapan fisik maupun emosional untuk mengatur, mengurus, dan melakukan aktivitas atas tanggung jawabnya sendiri tanpa banyak menggantungkan diri pada orang lain.

Belajar mandiri sangat penting untuk perkembangan seseorang karena: (1) orang-orang yang mengambil inisiatif dalam belajar lebih banyak dan lebih baik daripada orang yang tergantung pada pendidik; (2) cara belajar yang mandiri sejalan dengan proses alamiah perkembangan jiwa; (3) munculnya konsep-konsep atau teori-teori baru dalam pendidikan yang menekankan tanggungjawab pada siswa. ${ }^{11}$ Tentu saja peserta didik yang memiliki kemandirian belajar yang tinggi akan berusaha menyelesaikan tugas-tugas yang diberikan oleh guru sesuai dengan potensi yang dimiliki, sebaliknya peserta didik yang memiliki kemandirian yang rendah akan tergantung dengan orang lain. Berbagai fenomena yang terjadi dalam konteks proses belajar, seperti membolos, menyontek, dan mencari bocoran soal-soal ujian menunjukkan kurangnya kemandirian dalam belajar.

Berdasarkan observasi awal di MAN 1 Polewali Mandar, diperoleh data bahwa terdapat peserta didik yang mempunyai konsep diri rendah dengan gejala kurangnya percaya diri, ada peserta didik yang memiliki perasaan rendah diri, malu, gugup, dan ragu-ragu dalam menyampaikan pendapat, hanya diam ketika diberi kesempatan untuk bertanya saat proses pembelajaran di kelas atau di luar kelas, dan sulit berkata tidak pada sesuatu yang tidak ia sukai, beberapa peserta didik berpenampilan kurang rapi, beberapa peserta didik hanya mau berkelompok dengan teman sebangku dan teman dekatnya, beberapa peserta didik malas untuk mengerjakan PR, dan beberapa peserta didik terlihat ramai, gaduh, asyik mengobrol, dan bermain-main sendiri. ${ }^{12}$ Peserta didik yang demikian itu dapat dikatakan memiliki konsep diri yang rendah atau negatif. Kondisi ini menunjukkan adanya konsep diri dan kemandirian belajar peserta didik belum maksimal.

Permasalahan konsep diri rendah yang dialami oleh peserta didik, diperlukan upaya dari guru bimbingan konseling untuk memberikan bantuan terhadap peserta didik yang memiliki konsep diri rendah. Bila permasalahan ini terus dibiarkan, peserta didik akan gagal dalam studi karena dapat tinggal kelas atau kemungkinan juga bisa putus sekolah. Untuk mengantisipasi kemungkinan tersebut, maka peran guru bimbingan dan konseling adalah tempat memberikan layanan dan bimbingan kepada peserta didik dalam menyelesaikan permasalahan dan mampu membantu peserta didik untuk mengembangkan potensi yang dimiliki peserta didik. Melalui proses bimbingan konseling peserta didik dibimbing untuk mengarahkan hidupnya sendiri melalui berbagai pertimbangan, pembuatan rencana, pengambilan keputusan secara bijaksana dan bertanggung jawab atas keputusan yang diambil. Salah satu layanan konseling yang dapat digunakan yaitu layanan konseling kelompok, karena dalam layanan konseling kelompok peserta didik belajar berinteraksi dengan orang lain/teman, dan bersama-sama mencari jalan keluar untuk permasalahan tersebut.

\footnotetext{
${ }^{10}$ Umar Tirtarahardja dan S. L. La Sulo, Pengantar Pendidikan (Jakarta: Rineka Cipta, 2010), h. 50.

${ }^{11}$ Ihat Hatimah, Pembelajaran Berwawasan Masyarakat (Jakarta: Universitas Terbuka, 2008), h. 9.30.

${ }^{12}$ MAN 1 Polewali Mandar, Observasi Awal (Lampa: MAN 1 Polewali Mandar, 2019).
} 
Asumsi yang dipakai dalam penelitian ini adalah bahwa dalam pelatihan konsep diri akan terjadi proses interaksi antar individu. Diharapkan pelatihan konsep diri dijadikan sarana pemahaman nilai-nilai positif bagi peserta didik, khususnya konsep diri dibentuk tidak hanya dengan pendekatan personal namun dengan pendekatan kelompok seperti latihan asertif, yang akan lebih optimal karena para peserta didik tidak akan merasa terhakimi oleh keadaan sendiri, apalagi masalah konsep diri merupakan masalah yang banyak dialami oleh remaja. Pelatihan konsep diri dengan teknik assertive training merupakan suatu teknik mengajar manusia untuk mengekspresikan perasaan dan pikirannya secara jujur dan bertindak pada asumsi bahwa mereka memiliki hak untuk menjadi dirinya sendiri dan untuk mengekspresikan perasaan secara bebas. ${ }^{13}$

Salah satu faktor yang memengaruhi kemandirian peserta didik adalah konsep diri. Konsep diri membentuk harapan seseorang mengenai apa yang akan dilakukan. Pengharapan mengenai diri, menentukan bagaimana kita akan bertindak dalam hidup. Apabila kita berfikir bahwa kita bisa, maka kita akan cenderung berhasil, namun apabila kita berfikir bahwa mungkin gagal, maka kita telah menyiapkan diri kita untuk gagal. ${ }^{14}$

Berdasarkan uraian di atas, dapat dipahami bahwa pelatihan konsep diri memengaruhi kemandirian belajar. Namun belum diketahui tingkat konsep diri peserta didik dan pengaruhnya terhadap peningkatan kemandirian peserta didik. Masalah-masalah mengenai konsep diri dan kemandirian peserta didik yang ditemukan, peneliti beranggapan bahwa masalah tersebut penting untuk diteliti. Konsep diri dan kemandirian peserta didik sangat penting dalam menentukan proses pendidikan. Keduanya tidak terlepas dari rentang kehidupan manusia yang dipengaruhi oleh perkembangan manusia itu sendiri, sehingga peneliti akan melakukan penelitian korelasional sebab akibat dengan judul "Pengaruh Latihan Konsep Diri Terhadap Peningkatan Kemandirian Belajar Peserta Didik Di MAN 1 Polewali Kabupaten Polewali Mandar”.

\section{B. Rumusan Masalah}

Berdasarkan latar belakang masalah yang telah dipaparkan, maka fokus masalah dalam penelitian ini dapat dirumuskan sebagai berikut: "Apakah latihan konsep diri berpengaruh positif dan signifikan terhadap peningkatan kemandirian belajar peserta didik di MAN 1 Polewali Kabupaten Polewali Mandar"?

\section{Hipotesis Penelitian}

Berdasarkan rumusan masalah yang telah dikemukakan maka hipotesis penelitian yang dapat dirumuskan adalah: "Latihan konsep diri berpengaruh positif dan signifikan terhadap peningkatan kemandirian belajar peserta didik di MAN 1 Polewali Kabupaten Polewali Mandar".

\section{Tujuan Penelitian}

Sesuai dengan rumusan masalah penelitian yang telah dikemukakan maka tujuan yang ingin dicapai pada penelitian ini adalah: "Untuk mengetahui pengaruh latihan konsep diri terhadap peningkatan kemandirian belajar peserta didik di MAN 1 Polewali Kabupaten Polewali Mandar".

\footnotetext{
${ }^{13}$ Mochamad Nursalim, Strategi dan Intervensi Konseling (Jakarta: Academia Permata, 2013), h. 141.

${ }^{14} \mathrm{JF}$. Coulhoun \& JR. Acocella, Psikologi tentang Penyesuaian dan Hubungan Kemanusiaan, Alih bahasa: Prof. Dr. Ny. R.S Satmoko (Semarang: UNS Press, 2009), h. 66.
} 


\section{E. Manfaat Penelitian}

1. Dapat memberikan wawasan tentang hubungan latihan konsep diri dan kemandirian peserta didik dan dapat menjadi pertimbangan penelitian yang relevan dimasa mendatang.

2. Bagi guru, hasil penelitian ini diharapkan dapat memberikan wawasan bagi guru mengenai pengaruh latihan konsep diri terhadap kemandirian peserta didik, sehingga guru dapat meningkatkan kemandirian belajar peserta didik.

3. Bagi orang tua, hasil penelitian ini diharapkan dapat memberikan wawasan bagi orang tua mengenai pengaruh latihan konsep diri terhadap kemandirian anak, sehingga orang tua diharapkan dapat membantu anak dalam membentuk konsep diri yang positif agar anak memiliki kemandirian dalam belajar.

\section{METODE PENELITIAN}

Berdasarkan tujuan yang hendak dicapai maka penelitian ini termasuk jenis penelitian explanatory research, yaitu jenis penelitian yang bertujuan untuk mengetahui hubungan pengaruh antara dua buah variabel atau lebih. ${ }^{15}$ Secara lebih spesifik, penelitian ini merupakan penelitian ekspos fakto, yaitu meneliti hubungan sebab akibat yang tidak dimanipulasi atau diberi perlakuan (dirancang dan dilaksanakan) oleh peneliti. ${ }^{16}$ Penelitian ekspos fakto dengan pendekatan kuantitatif digunakan dalam penelitian ini untuk mengetahui dan memperoleh data dan informasi yang akurat tentang pengaruh pelatihan konsep diri terhadap peningkatan kemandirian peserta didik di MAN 1 Polewali Mandar.

Penelitian ini dilaksanakan di MAN 1 Polewali yang beralamat di Jl. Raya Majene No. 175 Desa Bonne-Bonne Kecamatan Mapilli Kabupaten Polewali Mandar. Penelitian ini dilaksanakan selama kurang lebih 3 (tiga) bulan, yaitu pada bulan Februari 2019 sampai dengan bulan April 2019.

Populasi dalam penelitian ini adalah semua peserta didik di MAN 1 Polewali Kabupaten Polewali Mandar sebanyak 1152 orang yang tersebar dalam kelas X, kelas XI, dan kelas XII. Metode pengambilan sampel yang digunakan dalam penelitian ini adalah probability sampling dengan teknik pengambilan sampel yang digunakan adalah simple random sampling, dimana pengambilan anggota sampel dipilih secara acak tanpa memperhatikan strata yang ada dalam populasi. Jumlah sampel dalam penelitian ini sebanyak 37 responden karena ukuran sampel yang layak dalam penelitian adalah antara 30 sampai dengan 500, untuk itu jumlah 37 sampel sebagai responden dianggap cukup mewakili keseluruhan populasi dalam penelitian ini.

Teknik yang digunakan dalam pengumpulan data adalah teknik observasi, kuesioner (angket), studi pustaka dan telaah dokumen. Teknik observasi yang digunakan dalam penelitian ini adalah teknik non partisipan agar peneliti dapat lebih fokus dalam melakukan pengamatan terhadap objek yang sedang diamati, sehingga data observasi yang dihasilkan benar-benar valid dan sesuai dengan kondisi yang sedang diamati. Observasi dilakukan terhadap komponen pelatihan konsep diri. Observasi juga dilakukan untuk mendapatkan data yang terkait dengan sarana dan prasarana MAN 1 Polewali Mandar.

\footnotetext{
${ }^{15}$ Syofian P. Siregar, Statistik Deskriptif Untuk Penelitian (Jakarta: Raja Grafindo Persada, 2013), h. 107.

${ }^{16}$ Nana Syaodih Sukmadinata, Metode Peneltian Pendidikan (Bandung: Remaja Rosdakarya, 2012), h. 55.
} 
Teknik angket digunakan untuk mengumpulkan data dari peserta didik MAN 1 Polewali Mandar terkait dengan konsep diri dan kemandirian peserta didik. Instrument angket dalam penelitian ini disusun secara tertutup dengan skala Likert dengan 4 alternatif jawaban, yaitu sangat sesuai (SS), sesuai (S), kurang sesuai (KS) dan tidak sesuai (TS).

Studi pustaka dalam penelitian ini merupakan pengumpulan data-data yang bersumber dari literatur atau referensi lain yang berhubungan dengan pokok bahasan sehingga peneliti menggunakan sebagai acuan analisa untuk memecahkan masalah terkait dengan objek penelitian. Dalam hal ini, penulis menelaah buku-buku literatur tentang pelatihan konsep diri dan kemandirian peserta didik. Sementara telaah dokumentasi digunakan untuk mengumpulkan data-data atau informasi tentang halhal yang ada kaitannya dengan masalah penelitian, dengan jalan melihat kembali sumber tertulis yang lalu baik berupa angka atau keterangan yang ada di MAN 1 Polewali Mandar.

Teknik atau metode analisis yang digunakan untuk menganalisis data-data yang diperoleh dalam penelitian ini adalah teknik analisis statistik deskriptif dan analisis statistik inferensial. Analisis statistik deskriptif digunakan untuk mendeskripsikan atau menggambarkan data hasil penelitian terkait dengan variabel pelatihan konsep diri (X) dan variabel peningkatan kemandirian peserta didik (Y). Perhitungan dilakukan dengan menggunakan bantuan computer pada software SPSS versi 21.

Statistik inferensial adalah teknik statistik yang digunakan untuk menganalisis data sampel dan hasilnya diberlakukan untuk populasi. Statistik inferensial yang dipakai adalah uji normalitas, analisis regresi linear sederhana, dan uji hipotesis (Uji-t dan Uji Koefisien Determinasi). Uji normalitas digunakan untuk mengetahui apakah dalam model regresi, variabel pengganggu atau residual memiliki distribusi normal atau tidak. Uji normalitas data menggunakan uji KolmogorofSmirnov dengan bantuan komputr pada software SPSS versi 21.

Uji-t statistik, digunakan untuk melihat hubungan atau pengaruh antara variabel independen secara individual terhadap variabel dependen pada taraf signifikan $\alpha=0,05$. Uji-t digunakan untuk menguji apakah variabel pelatihan konsep diri (X) mempunyai pengaruh yang positif dan signifikan terhadap variabel peningkatan kemandirian belajar peserta didik (Y) atau tidak. Koefisien determinasi merupakan ukuran yang dapat dipergunakan untuk mengetahui besarnya pengaruh variabel bebas terhadap variabel tidak bebas (terikat). Untuk menentukan nilai $\mathrm{R}^{2}$, dengan melihat hasil output SPSS.

\section{HASIL PENELITIAN DAN PEMBAHASAN}

\section{A. Deskripsi Data Hasil Penelitian}

Deskripsi data berisi rangkaian data yang berhasil dikumpulkan, baik data utama maupun data pendukung yang diperlukan untuk pengujian hipotesis. Penelitian ini membahas dua variabel yang terdiri dari satu variabel bebas dan satu variabel terikat. Pada penelitian ini, latihan konsep diri sebagai variabel bebas $(\mathrm{X})$ dan kemandirian belajar sebagai variabel terikat (Y).

Data primer dalam penelitian ini terdiri dari data konsep diri dan kemandirian belajar peserta didik di MAN 1 Polewali Mandar. Data tentang konsep diri dan kemandirian belajar peserta didik diperoleh melalui instrumen angket. Deskripsi data penelitian disajikan menggunakan teknik statistik deskriptif dan statistik inferensial yang tujuanya lebih pada penggambaran data. Deskripsi data hasil statistik deskriptif masing-masing variabel meliputi: nilai rerata (Mean), median (Me), modus (Mo), standar deviasi (SD), dan Tabel distribusi frekuensi. Sedangkan deskripsi data hasil statistik inferensial meliputi pengujian hipotesis beserta pengujian persyaratan analisisnya. 


\section{Hasil Analisis Deskriptif}

Analisis deskriptif digunakan untuk mempermudah dalam penggambaran data. Penghitungan analisis deskriptif data dilakukan dengan menggunakan program SPSS Windows for 21. Hasil analisis deskriptif dapat dilihat pada tabel berikut:

Tabel 1.

Hasil Analisis Deskriptif Variabel X dan Y

\begin{tabular}{|l|c|c|}
\hline \multicolumn{1}{|c|}{ Deskripsi } & Latihan Konsep Diri & Kemandirian Belajar \\
\hline $\mathrm{N}$ & 37 & 37 \\
\hline Mean & 75.36 & 55.05 \\
\hline Median & 75.00 & 56.00 \\
\hline Mode & 70 & 62 \\
\hline Std. Deviation & 7.810 & 8.577 \\
\hline Variance & 60.998 & 73.559 \\
\hline Range & 37 & 35 \\
\hline Minimum & 60 & 37 \\
\hline Maximum & 97 & 72 \\
\hline Sum & 2788 & 2037 \\
\hline
\end{tabular}

Sumber: Hasil olah data penelitian, 2019.

a. Variabel Latihan Konsep Diri (X)

Berdasarkan data pada tabel 1 dapat dideskripsikan bahwa konsep diri yang dimiliki 37 peserta didik MAN 1 Polewali Mandar setelah melakukan latihan konsep diri memiliki skor terendah sebesar 60, skor tertinggi 97, skor mean (rata-rata) 75,36, skor tengah (median) 76, skor yang sering muncul (mode) 70. Dari data-data tersebut kemudian dicari kecenderungan skor rata-rata variabel konsep diri dengan cara mengakategorikan skor rerata ideal yang seharusnya diperoleh. Langkah yang dilakukan yaitu mencari jumlah kelas interval yang dihitung dengan rumus sebagai berikut:

$$
\mathrm{K}=1+3,3 \log \mathrm{n}
$$

Dimana: $\mathrm{K}=$ Jumlah kelas interval

$\mathrm{n} \quad=$ Jumlah data

$\log =$ Logaritma

Hasil yang diperoleh adalah: $\mathrm{K}=1+3,3 \log 99=1+3,3.1,996=1+6,5868=7,5868$

Jumlah kelas interval yang diperoleh yaitu 7,5868 yang kemudian dibulatkan menjadi 8 . Selanjutnya mencari rentang data, dilakukan dengan mengurangi data terbesar dengan data terkecil (97 - 60), sehingga hasilnya 37. Kemudian mencari panjang kelas, dilakukan dengan membagi rentang data dengan jumlah kelas, sehingga panjang kelasnya yaitu 4,625. Panjang kelas tersebut kemudian dibulatkan menjadi 4. Dengan demikian dapat diperoleh distribusi frekuensi dan persentase konsep diri peserta didik di MAN 1 Polewali Mandar pada tabel berikut:

Tabel 2.

Distribusi Frekuensi dan Persentase Konsep Diri Peserta Didik

\begin{tabular}{|c|c|c|c|}
\hline No. & Interval Skor & Frekuensi & Persentase (\%) \\
\hline 1 & $60-64$ & 1 & 2,70 \\
\hline 2 & $65-69$ & 2 & 5,41 \\
\hline 3 & $70-74$ & 12 & 32,43 \\
\hline
\end{tabular}




\begin{tabular}{|c|c|c|c|}
\hline 4 & $75-79$ & 9 & 24,32 \\
\hline 5 & $80-84$ & 8 & 21,62 \\
\hline 6 & $85-89$ & 2 & 5,41 \\
\hline 7 & $90-94$ & 2 & 5,41 \\
\hline 8 & $95-99$ & 1 & 2,70 \\
\hline & Jumlah & $\mathbf{3 7}$ & $\mathbf{1 0 0}$ \\
\hline
\end{tabular}

Sumber: Hasil olah data penelitian, 2019.

Dari tabel 2 dapat dilihat bahwa responden (peserta didik MAN 1 Polewali Mandar) yang memiliki konsep diri antara 60-64 ada 1 orang (2,70\%), 65-69 ada 2 orang (5,41\%), 70-74 ada 12 orang $(32,43 \%), 75-79$ ada 9 orang $(24,32 \%), 80-84$ ada 8 orang $(21,62 \%), 85-89$ ada 2 orang (5,41\%), 90-94 ada 2 orang (5,41\%), dan 95-99 ada 1 orang (2,70\%). Untuk mengetahui kecenderungan rata-rata skor variabel konsep diri dengan mengkategorikan dengan skor rerata ideal yang seharusnya diperoleh, maka jumlah item yang dipakai sebanyak 25 item. Skornya mulai dari 1 sampai 4. Dengan demikian, nilai maksimal yaitu 4 × $25=100$ dan nilai minimal yaitu 1 x $25=25$. Mean ideal $=(100+25) / 2=62,5$. Standar Deviasi idealnya $=(100-25) / 6=12,5$. Setelah didapat mean ideal dan Standar Deviasi ideal, maka dapat dikategorisasikan sebagai berikut:
1) $>(62,5+12,5)$ sampai 97
$=$ Tinggi
2) $(62,5-12,5)$ sampai $(62,5+12,5)=$ Sedang
3) $<(62,5-12,5)$ sampai 0
$=$ Rendah

Berdasarkan hasil konvensi di atas, maka dapat disajikan tabel tingkat skor variabel konsep diri sebagai berikut:

Tabel 3.

Tingkat Skor Variabel Konsep Diri

\begin{tabular}{|c|c|c|c|}
\hline Interval Skor & Kategori & Frekuensi & Persentase (\%) \\
\hline $76-97$ & Tinggi & 18 & 48,65 \\
\hline $50-75$ & Sedang & 19 & 51,35 \\
\hline $0-49$ & Rendah & 0 & 0,00 \\
\hline & Jumlah & $\mathbf{3 7}$ & $\mathbf{1 0 0}$ \\
\hline
\end{tabular}

Sumber: Hasil olah data penelitian, 2019.

Berdasarkan tabel 3 tersebut maka dapat disimpulkan bahwa sebagian besar konsep diri peserta didik MAN 1 Polewali Mandar tergolong sedang dengan persentase 51,35\%. Jika dilihat dari skor rata-rata sebesar 75.36 maka skor rata-rata tersebut juga tergolong sedang. Hal tersebut berarti bahwa peserta didik MAN 1 Polewali Mandar telah memiliki pandangan mengenai dirinya sendiri, memahami tentang perilaku, sudah mampu menilai mengenai persepsi tentang diri sendiri, mampu mempersepsikan mengenai kesehatan dirinya, penampilan dirinya dan keadaan tubuhnya, mampu melakukan hal yang sesuai dengan norma-norma, puas terhadap dirinya dan merasa menjadi pribadi yang tepat, menunjukkan peran sebagai anggota keluarga dan menilai mengenai interaksi dirinya dengan lingkungan. Namun hal-hal tersebut masih belum optimal.

b. Variabel Kemandirian Belajar (Y)

Berdasarkan data pada tabel 1 dapat dideskripsikan bahwa kemandirian belajar yang dimiliki 37 responden (peserta didik MAN 1 Polewali Mandar) memiliki skor terendah sebesar 37, skor tertinggi 72 , skor mean (rata-rata) 55.05, skor tengah (median) 56, skor yang sering muncul (mode) 
62. Dari data-data tersebut kemudian dicari kecenderungan skor rata-rata variabel konsep diri dengan cara mengakategorikan skor rerata ideal yang seharusnya diperoleh.

Jumlah kelas interval yang diperoleh yaitu 7,5868 (=8). Rentang data $=72-37=35$. Panjang kelas $=$ rentang data/jumlah kelas $=35 / 8=4,375(=4)$. Dengan demikian dapat diperoleh distribusi frekuensi dan persentase kemandirian belajar peserta didik di MAN 1 Polewali Mandar seperti pada tabel berikut:

Tabel 4.

Distribusi Frekuensi dan Persentase Kemandirian Belajar

\begin{tabular}{|c|c|c|c|}
\hline No. & Interval Skor & Frekuensi & Persentase (\%) \\
\hline 1 & $37-41$ & 2 & 5,41 \\
\hline 2 & $42-46$ & 3 & 8,11 \\
\hline 3 & $47-51$ & 6 & 16,22 \\
\hline 4 & $52-56$ & 7 & 18,92 \\
\hline 5 & $57-61$ & 9 & 24,32 \\
\hline 6 & $62-66$ & 5 & 13,51 \\
\hline 7 & $67-71$ & 4 & 10,81 \\
\hline 8 & $72-76$ & 1 & 2,70 \\
\hline & Jumlah & $\mathbf{3 7}$ & $\mathbf{1 0 0}$ \\
\hline
\end{tabular}

Sumber: Hasil olah data penelitian, 2019.

Dari tabel 4 dapat dilihat bahwa responden (peserta didik MAN 1 Polewali Mandar) yang memiliki kemandirian belajar antara $37-41$ ada 2 orang (5,41\%), 42-46 ada 3 orang $(8,11 \%), 47-51$ ada 6 orang (16,22\%), 52-56 ada 7 orang (18,92\%), 57-61 ada 9 orang $(24,32 \%), 62-66$ ada 5 orang $(13,51 \%), 67-71$ ada 4 orang $(10,81 \%)$, dan $72-76$ ada 1 orang $(2,70 \%)$.

Untuk mengetahui kecenderungan rata-rata skor variabel kemandirian belajar dengan mengkategorikan dengan skor rerata ideal yang seharusnya diperoleh, maka jumlah item yang dipakai sebanyak 19 item. Skornya mulai dari 1 sampai 4. Dengan demikian, nilai maksimal yaitu 4 x $19=$ 76 dan nilai minimal yaitu $1 \times 19=19$. Mean ideal $=(76+19) / 2=47,5$. Standar Deviasi idealnya $=$ $(76-19) / 6=9,5$. Setelah didapat mean ideal dan Standar Deviasi ideal, maka dapat dikategorisasikan sebagai berikut:

1) $>(47,5+9,5)$ sampai $72 \quad=$ Tinggi

2) $(47,5-9,5)$ sampai $(47,5+9,5)=$ Sedang

3) $<(47,5-9,5)$ sampai $0 \quad=$ Rendah

Berdasarkan hasil konvensi di atas, maka dapat disajikan tabel tingkat skor variabel kemandirian belajar sebagai berikut:

Tabel 5.

Tingkat Skor Variabel Kemandirian Belajar

\begin{tabular}{|c|c|c|c|}
\hline Interval Skor & Kategori & Frekuensi & Persentase (\%) \\
\hline $58-72$ & Tinggi & 14 & 37,84 \\
\hline $38-57$ & Sedang & 22 & 58,46 \\
\hline $0-37$ & Rendah & 1 & 2,70 \\
\hline & Jumlah & $\mathbf{3 7}$ & $\mathbf{1 0 0}$ \\
\hline
\end{tabular}

Sumber: Hasil olah data penelitian, 2019. 
Berdasarkan tabel 5 tersebut maka dapat disimpulkan bahwa sebagian besar kemandirian belajar responden (peserta didik MAN 1 Polewali Mandar) tergolong sedang dengan persentase $58,46 \%$. Jika dilihat dari skor rata-rata kemandirian belajar sebesar 55.05 maka skor rata-rata tersebut juga tergolong sedang. Hal tersebut berarti bahwa peserta didik MAN 1 Polewali Mandar telah mengetahui dengan pasti apa yang ingin dia capai dalam kegiatan belajarnya, dapat memilih sumber belajarnya sendiri dan mengetahui dimana dia harus mencari sumber belajar tersebut, serta dapat menilai tingkat kemampuan yang diperlukan untuk menyelesaikan masalah yang dijumpai dalam kehidupan sehari-hari. Namun hal-hal tersebut masih belum optimal.

\section{Hasil Analisis Statistik Inferensial}

Hasil analisis statistik inferensial trhadap data hasil penelitian terdiri dari uji prasyarat statistik dan pengujian hipotesis. Uji prasyarat analisis yang digunakan pada penelitian ini terdiri dari uji normalitas dan uji linieritas. Syarat yang harus dipenuhi untuk uji prasyarat yaitu data penelitian harus normal dan memiliki hubungan linier.

Data yang telah memenuhi syarat selanjutnya dianalisis lebih lanjut untuk membuktikan hipotesis. Uji hipotesis yang digunakan pada penelitian ini yaitu uji korelasi sederhana, regresi sederhana, uji-t, dan uji koefisien determinasi. Berikut ini penjelasan masing-masing bagian.

\section{a. Uji Prasyarat Analisis}

Uji prasyarat terdiri dari uji normalitas dan linieritas. Data-data yang diuji dalam uji prasyarat analisis merupakan hasil pengolahan data-data variabel latihan konsep diri dan variabel kemandirian belajar yang dimiliki oleh 37 orang responden (peserta didik MAN 1 Polewali Mandar). Berikut hasil uji prasyarat yang digunakan pada penelitian ini:

1) Uji Normalitas

Uji normalitas dimakusdkan untuk mengetahui apakah distribusi data dalam penelitian normal atau tidak. Uji normalias dilakukan melaui uji Kolmogorov-Smirnov melalui bantuan SPSS Windows for 21 dengan taraf signifikansi 5\%. Data berdistribusi normal jika nilai Asymp. Sig. > 0,05. Rangkuman hasil uji normalitas dapat dilihat pada tabel berikut:

Tabel 6.

Rangkuman Hasil Uji Normalitas

\begin{tabular}{|c|c|c|c|c|}
\hline No. & Variabel & Asymp. Sig & Signifikansi & Keterangan \\
\hline 1 & Latihan Konsep Diri & 0,655 & 0,05 & Normal \\
\hline 2 & Kemandirian Belajar & 0,878 & 0,05 & Normal \\
\hline
\end{tabular}

Sumber: Hasil olah data penelitian, 2019.

Dari tabel 6 tersebut dapat dikatakan bahwa distribusi data dari kedua variabel dalam penelitian ini normal karena nilai Asymp. Sig dari masing-masing variabel lebih besar dari 0,05.

2) Uji Linieritas

Uji linieritas dilakukan menggunakan Test for Linearity pada taraf signifikansi $\alpha=0,05$ dengan menggunakan bantuan SPSS Windows for 21. Hasil pengujian dapat dilihat pada output Tabel ANOVA kolom Sig. baris Linierity. Hubungan dua variabel dikatakan linier apabila hasil perhitungan mempunyai nilai signifikansi kurang dari 0,05. Hasil analisis uji linieritas dapat dibaca pada tabel berikut: 
Tabel 7.

Hasil Uji Linieritas Latihan Konsep Diri dan Kemandirian Belajar

\begin{tabular}{|c|c|c|c|c|c|c|c|}
\hline & & & $\begin{array}{l}\text { Sum of } \\
\text { Squares }\end{array}$ & Df & $\begin{array}{l}\text { Mean } \\
\text { Square }\end{array}$ & $\mathrm{F}$ & Sig \\
\hline \multirow{4}{*}{$\begin{array}{l}\text { Kemandirian } \\
\text { Belajar } \\
\text { Latihan } \\
\text { Konsep Diri }\end{array}$} & & (Combined) & 2197,482 & 2 & 69,591 & 1,123 & ,878 \\
\hline & $\begin{array}{l}\text { Between } \\
\text { Groups }\end{array}$ & $\begin{array}{l}\text { Linierity } \\
\text { Deviation }\end{array}$ & 910,045 & 1 & 910,045 & 14,69 & ,000 \\
\hline & & from Linierity & 1386,473 & 1 & 41,814 & 699 & 655 \\
\hline & $\begin{array}{l}\text { Within } \\
\text { Groups } \\
\text { Total }\end{array}$ & & $\begin{array}{l}6546,227 \\
9113,000\end{array}$ & $\begin{array}{l}34 \\
35\end{array}$ & 61,968 & & \\
\hline
\end{tabular}

Sumber: Hasil olah data penelitian, 2019.

Berdasarkan tabel 7 dapat diketahui bahwa nilai signifikansi uji linieritas variabel kemandirian belajar dan latihan konsep diri sebesar 0,000 . Nilai signifikansi tersebut kurang dari 0,05 $(0,000<0,05)$, sehingga dapat disimpulkan bahwa kedua variabel yaitu kemandirian belajar dan latihan konsep diri memiliki hubungan yang linier. Jadi hubungan dua variabel yaitu latihan konsep diri (X) dengan kemandirian belajar (Y) merupakan hubungan yang linier.

\section{b. Pengujian Hipotesis}

Pengujian hipotesis adalah suatu prosedur yang dilakukan dengan tujuan memutuskan apakah menerima atau menolak rancangan hipotesis. Uji hipotesis dilakukan setelah semua uji prasyarat terpenuhi. Berdasarkan hasil uji prasyarat, dapat diketahui bahwa data penelitian ini berdistribusi normal dan memiliki hubungan yang linier. Teknik analisis yang digunakan untuk menguji hipotesis yang telah dikemukakan sebelumnya yaitu "latihan konsep diri berpengaruh positif dan signifikan terhadap peningkatan kemandirian belajar peserta didik di MAN 1 Polewali Mandar" adalah teknik analisis regresi sederhana.

Pengujian hipotesis tersebut bertujuan untuk mengetahui pengaruh latihan konsep diri terhadap peningkatan kemandirian belajar peserta didik di MAN 1 Polewali Mandar. Latihan konsep diri sebagai variabel bebas (X) dan kemandirian belajar sebagai variabel terikat (Y). Penghitungan regresi linier menggunakan data skor angket konsep diri dan data skor angket kemandirian belajar peserta didik. Penghitungan dilakukan dengan bantuan program SPSS Windows for 21.

Hipotesis penelitian yang diajukan pada penelitian ini dalam bentuk kalimat yaitu:

H0 : Latihan konsep diri tidak berpengaruh positif dan signifikan terhadap peningkatan kemandirian belajar peserta didik di MAN 1 Polewali Mandar.

$\mathrm{Ha}$ : Latihan konsep diri berpengaruh positif dan signifikan terhadap peningkatan kemandirian belajar peserta didik di MAN 1 Polewali Mandar.

Hipotesis yang diajukan dalam bentuk statistik yaitu:

H0 $: \rho=0$

На : $\rho \neq 0$

Hasil keluaran (output) yang pertama pada penghitungan analisis regresi sederhana adalah hasil nilai korelasi sederhana (R). Nilai korelasi sederhana menunjukkan ada atau tidaknya hubungan antara dua variabel. Apabila nilai R semakin mendekati 1, maka hubungan yang terjadi semakin kuat. Nilai keeratan hubungan/korelasi atau pengaruh antar variabel dikategorikan menjadi tujuh tingkat. 
Nilai 0,00 didak ada hubungan, skala nilai $0,00-0,20$ memiliki tingkat hubungan sangat rendah. Skala nilai 0,209-0,40 memiliki tingkat hubungan rendah. Tingkat hubungan sedang berada pada skala nilai 0,409-0,70. Skala nilai untuk hubungan kuat yaitu 0,709-0,90. Skala nilai 0,909-0,99 memiliki tingkat hubungan sangat kuat dan nilai 1,000 memeliki hubungan sempurna. ${ }^{17}$

Hasil nilai korelasi sederhana antara variabel latihan konsep diri dan kemandirian belajar dapat dibaca pada tabel 8 berupa tabel Model Summary.

Tabel 8.

Hasil Nilai Korelasi Sederhana Variabel Latihan Konsep Diri dan Kemandirian Belajar

Model Summary

\begin{tabular}{|c|c|c|c|c|}
\hline Model & $\mathrm{R}$ & $\mathrm{R}$ Square & Adjusted R Square & $\begin{array}{c}\text { Std. Error of the } \\
\text { Estimate }\end{array}$ \\
\hline 1 &, $641^{\mathrm{a}}$ &, 411 &, 137 & 8,173 \\
\hline
\end{tabular}

a. Predictors: (Constant), Latihan Konsep Diri

b. Dependent Variable: Kemandirian Belajar Sumber: Hasil olah data penelitian, 2019.

Berdasarkan output Model Summary pada tabel 8, nilai korelasi sederhana antara variabel latihan konsep diri dan kemandirian belajar adalah sebesar 0,641. Besar korelasi bernilai positif sehingga menunjukkan terdapat korelasi positif antara dua variabel. Nilai tersebut berada pada rentang 0,409 - 0,70 dan termasuk ke dalam kategori sedang. Jadi dapat disimpulkan bahwa nilai korelasi yang terjadi antara variabel latihan konsep diri dan kemandirian belajar bernilai sedang atau memiliki hubungan yang cukup kuat.

Hasil keluaran (output) kedua pada analisis regresi sederhana yaitu nilai signifikansi regresi sederhana antara variabel latihan konsep diri dan kemandirian belajar. Apabila nilai signifikansi < 0,05, maka H0 ditolak atau Ha diterima, dan apabila nilai signifikansi $>0,05$ maka H0 diterima atau Ha ditolak.

Hasil nilai signifikansi variabel latihan konsep diri dan variabel kemandirian belajar dapat dibaca pada tabel 9 berikut:

Tabel 9.

Hasil Nilai Signifikansi Regresi Sederhana Variabel Latihan Konsep Diri dan Kemandirian Belajar

\begin{tabular}{|l|r|r|r|r|r|}
\hline \multicolumn{7}{|c|}{ ANOVA $^{\mathbf{b}}$} \\
\hline Model & Sum of Squares & $d f$ & Mean Square & $F$ & \multicolumn{1}{c|}{ Sig. } \\
\hline Regression & 910,045 & 1 & 910,045 & 14,69 & $\mathbf{. 0 0}^{\text {a }}$ \\
Residual & 1386,473 & 35 & 61,968 & & \\
Total & 9113,000 & 36 & & & \\
\hline \multicolumn{2}{|l}{ a. Predictors: (Constant), Latihan Konsep Diri } \\
\hline
\end{tabular}

\footnotetext{
${ }^{17}$ Suharsimi Arikunto, Prosedur Penelitian Suatu Pendekatan Praktik (Jakarta: Rineka Cipta, 2013), h. 140.
} 


\begin{tabular}{|c|c|c|c|c|c|}
\hline \multicolumn{6}{|c|}{ ANOVA $^{b}$} \\
\hline Model & Sum of Squares & $d f$ & Mean Square & $F$ & Sig. \\
\hline Regression & 910,045 & 1 & 910,045 & 14,69 & $.000^{\circ}$ \\
\hline Residual & 1386,473 & 35 & 61,968 & & \\
\hline Total & 9113,000 & 36 & & & \\
\hline
\end{tabular}

Sumber: Hasil olah data penelitian, 2019.

Berdasarkan tabel 9 (tabel ANOVA) pada kolom sig. diperoleh nilai signifikansi sebesar 0,000. Hal ini menunjukkan bahwa $\mathrm{H} 0$ ditolak dan Ha diterima karena nilai signifikansi lebih kecil dari $0,05(0,000<0,05)$.

Jadi, dapat disimpulkan bahwa latihan konsep diri berpengaruh positif dan signifikan terhadap peningkatan kemandirian belajar peserta didik di MAN 1 Polewali Mandar.

Langkah selanjutnya yaitu menentukan nilai prediksi variabel terikat. Penentuan berdasarkan nilai konstanta dan nilai koefisien regresi yang dihasilkan pada analisis regresi sederhana. Nilai-nilai tersebut selanjutnya dimasukkan ke dalam rumus persamaan regresi linier sederhana. Rumus persamaan regresi linier sederhana adalah:

$$
\hat{\mathrm{Y}}=\mathrm{a}+\mathrm{bX}
$$

Dimana $\hat{Y}$ adalah nilai yang diprediksikan atau variabel terikat, a yaitu konstanta, $\mathrm{b}$ adalah nilai koefisien regresi, dan $\mathrm{X}$ melambangkan variabel bebas.

Besarnya nilai-nilai yang akan dimasukkan pada rumus persamaan regresi linier sederhana tersebut dapat dibaca pada tabel 10 (tabel Coefficients). Berdasarkan output Coefficients kolom Unstandardized Coefficients B pada tabel 10 diketahui konstanta bernilai 41,819 dan koefisien regresi bernilai 0,358 . Persamaan regresi linier sederhana yang terbentuk sebagai berikut:

$$
\begin{aligned}
& \hat{Y}=a+b X \\
& \hat{Y}=41,819+0,358 X
\end{aligned}
$$

\section{Keterangan:}

$$
\begin{aligned}
& \hat{Y}=\text { Kemandirian belajar } \\
& X=\text { Latihan konsep diri } \\
& a=\text { konstanta }=41,819 \\
& b=\text { koefisien regresi }=0,358
\end{aligned}
$$

Tabel 10.

Hasil Nilai B pada Analisis Regresi Sederhana Variabel Latihan Konsep Diri dan Kemandirian Belajar 


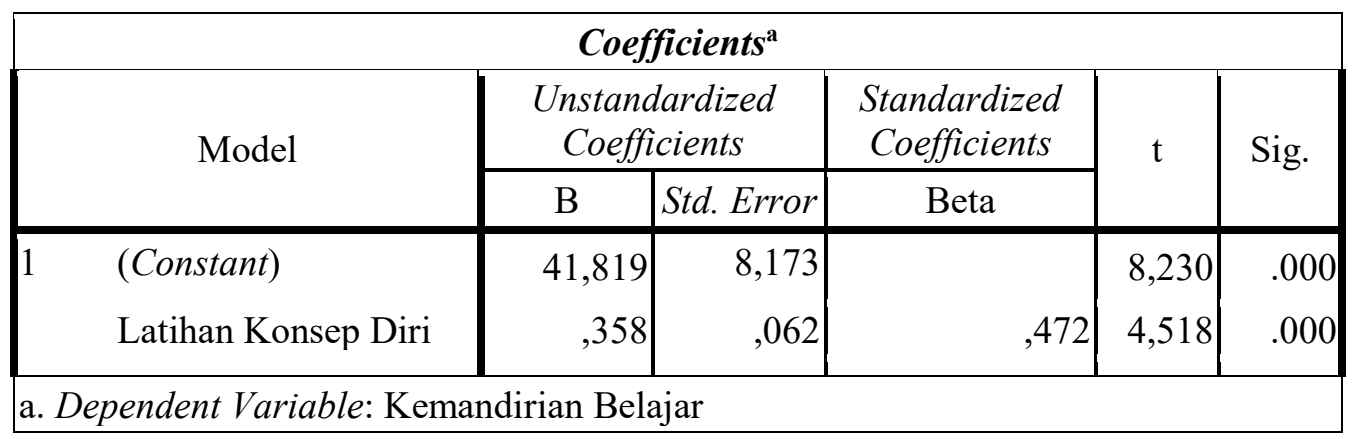

Sumber: Hasil olah data penelitian, 2019.

Persamaan regresi tersebut dapat dijelaskan sebagai berikut:

1) Nilai konstanta (a) sebesar 41,819 . Hal tersebut dapat diartikan jika latihan konsep diri bernilai 0 , maka kemandirian belajar bernilai 41,819.

2) Nilai koefisien regresi (b) sebesar 0,358. Hal tersebut dapat diartikan jika latihan konsep diri mengalami kenaikan 1 satuan, maka kemandirian belajar akan mengalami peningkatan sebesar 0,358 satuan. Koefisien tersebut bernilai positif yang berarti terdapat hubungan yang positif antara latihan konsep diri dan kemandirian belajar. Semakin sering latihan konsep diri, maka semakin tinggi pula kemandirian belajar.

Langkah selanjutnya yaitu menghitung nilai koefisien determinasi dari hasil analisis regresi linier sederhana. Nilai koefisien determinasi menunjukkan seberapa besar kontribusi pengaruh variabel bebas terhadap variabel terikat. Nilai koefisien korelasi di kolom R Square $\left(\boldsymbol{r}^{2}\right)$ pada output Model Summary. Perhitungan nilai koefisien determinasi menggunakan rumus berikut:

$$
\mathrm{KP}=\boldsymbol{r}^{2} \times 100 \%
$$

di mana KP adalah nilai koefisien determinasi dan $\boldsymbol{r}$ melambangkan nilai koefisien korelasi. Nilai koefisien determinasi untuk pengaruh variabel latihan konsep diri terhadap variabel kemandirian belajar dapat dibaca pada tabel Model Summary ${ }^{\mathrm{b}}$ (tabel 8).

Berdasarkan output Model Summary kolom R Square $\left(\boldsymbol{r}^{2}\right)$ pada tabel 8, nilai koefisien korelasi $\left(\boldsymbol{r}^{2}\right)$ yang dihasilkan adalah 0,411 . Persamaan nilai koefisien determinasi yang terbentuk adalah sebagai berikut:

$$
\mathrm{KP}=\boldsymbol{r}^{2} \times 100 \%=0,411 \times 100 \%=41,1 \%
$$

Dengan demikian, dapat disimpulkan bahwa nilai koefisien determinasi pengaruh variabel latihan konsep diri terhadap variabel peningkatan kemandirian belajar sebesar $41,1 \%$. Artinya, tingkat pengaruh latihan konsep diri terhadap peningkatan kemandirian belajar peserta didik MAN 1 Polewali Mandar adalah sebesar 41,1\%. Sedangkan sisanya yaitu 58,9\% dipengaruhi oleh faktor lain di luar bahasan penelitian.

\section{B. Pembahasan}

Penelitian ini bertujuan untuk mengetahui pengaruh latihan konsep diri terhadap peningkatan kemandirian belajar peserta didik di MAN 1 Polewali Mandar. Metode penelitian yang digunakan dalam penelitian ini adalah non eksperimen jenis expost facto. 
Pengaruh latihan konsep diri terhadap peningkatan kemandirian belajar peserta didik dapat diketahui dengan melaksanakan uji pasyarat yaitu uji normlitas dan uji linieritas. Uji normalitas data dilakukan untuk mengetahui apakah data berdistribusi normal atau tidak. Berdasarkan pengujian menggunakan program SPSS Windows for 21, diperoleh nilai signifikansi pada kolom Asymp sig (2tailed). Nilai signifikansi variabel latihan konsep diri sebesar 0,655 dan kemandirian belajar sebesar 0,878. Hasil tersebut menunjukkan bahwa distribusi data dari kedua variabel dalam penelitian ini normal karena nilai Asymp. Sig dari masing-masing variabel lebih besar dari 0,05.

Uji linieritas digunakan untuk mengetahui apakah dua variabel memiliki hubungan yang linier atau tidak secara signifikan. Berdasarkan penghitungan menggunakan program SPSS Windows for 21, diperoleh nilai signifikansi pada tabel ANOVA sebesar 0,000. Nilai signifikansi yang dihasilkan lebih kecil dari $0,05(0,000<0,05)$. Hasil tersebut menunjukkan antara variabel latihan konsep diri dan variabel kemandirian belajar memiliki hubungan yang linier.

Latihan konsep diri berpengaruh terhadap peningkatan kemandirian belajar peserta didik. Hal ini dibuktikan dengan nilai signifikansi lebih kecil dari $0,05(0,000<0,05)$, sehingga dinyatakan bahwa latihan konsep diri memengaruhi peningkatan kemandirian belajar peserta didik di MAN 1 Polewali Mandar. Berdasarkan hasil analisis korelasi sederhana, diketahui koefisien korelasi antara latihan konsep diri dan peningkatan kemandirian belajar sebesar 0,641. Nilai korelasi sederhana berada pada interval nilai 0,409-0,70, sehingga hubungan antara kedua variabel tergolong sedang.

Arah hubungan kedua variabel tersebut adalah positif karena nilai (R) positif. Hal tersebut menunjukkan apabila semakin sering latihan konsep diri, maka semakin meningkat kemandirian belajar peserta didik di MAN 1 Polewali Mandar.

Selain itu, diperoleh angka R² (R Square) sebesar 0,411. Hasil R² (R Square) menunjukkan kontribusi pengaruh variabel latihan konsep diri terhadap peningkatan kemandirian belajar sebesar $41,1 \%$, sedangkan sisanya yaitu 58,9\% dipengaruhi oleh faktor lain di luar bahasan penelitian.

Hasil analisis regresi linier sederhana menunjukkan hasil bahwa H0 ditolak dan Ha diterima karena nilai signifikansi $0,000<0,05$. Berdasarkan hasil tersebut, dapat disimpulkan bahwa latihan konsep diri berpengaruh positif dan signifikan terhadap peningkatan kemandirian belajar peserta didik di MAN 1 Polewali Mandar. Persamaan regresi pada pengaruh variabel latihan konsep diri terhadap peningkatan kemandirian belajar yang dihasilkan adalah:

$$
\hat{\mathrm{Y}}=41,819+0,358 \mathrm{X}
$$

Nilai konstanta (a) sebesar 41,819 dapat diartikan bahwa jika latihan konsep diri bernilai 0 , maka kemandirian belajar bernilai 41,819. Nilai koefisien regresi (b) sebesar 0,358 yang dapat diartikan bahwa jika latihan konsep diri mengalami kenaikan 1 satuan, maka kemandirian belajar akan mengalami peningkatan sebesar 0,358 satuan. Koefisien tersebut bernilai positif yang berarti terdapat pengaruh yang positif dari latihan konsep diri terhadap kemandirian belajar. Semakin sering latihan konsep diri, maka semakin meningkat pula kemandirian belajar peserta didik di MAN 1 Polewali Mandar. Sebaliknya peserta didik yang memiliki konsep diri rendah karena kurangnya latihan konsep diri maka akan semakin rendah kemandirian belajarnya.

Temuan penelitian bahwa latihan konsep diri mempunyai pengaruh terhadap kemandirian belajar tersebut sesuai dengan pendapat Hurlock bahwa keberhasilan seseorang untuk mandiri adalah harus memiliki konsep diri yang stabil karena dapat membantu seseorang memandang dirinya dengan 
cara yang lebih konsisten dan akhirnya dapat meningkatkan kemandirian dan memperkecil rasa ketidakmampuan. ${ }^{18}$ Juga sesuai dengan pendapat Lintina bahwa siswa dengan konsep diri positif akan melakukan hal-hal yang positif yang dapat membuat siswa menjadi lebih mandiri. Sedangkan siswa dengan konsep diri negatif tidak dapat mengatur diri sendiri dan tergantung pada orang lain. Hal itu menyebabkan, siswa tersebut tidak mandiri. ${ }^{19}$

Berdasarkan uraian tersebut, maka dapat disimpulkan bahwa hipotesis dalam penelitian ini, yaitu "latihan konsep diri berpengaruh positif dan signifikan terhadap peningkatan kemandirian belajar peserta didik di MAN 1 Polewali Kabupaten Polewali Mandar" adalah diterima. Dengan kata lain semakin sering peserta didik latihan konsep diri, maka kemandirian belajar peserta didik akan semakin meningkat. Hasil penelitian ini memberikan gambaran pada guru bahwa konsep diri bengaruh terhadap kemandirian belajar. Dengan demikian, guru hendaknya dapat membentuk kemandirian belajar peserta didik dengan cara meningkatkan konsep diri peserta didik melalui latihan konsep diri.

\section{PENUTUP}

\section{A. Simpulan}

Berdasarkan hasil penelitian dan pembahasan terkait dengan pengaruh latihan konsep diri terhadap peningkatan kemandirian belajar peserta didik di MAN 1 Polewali Kabupaten Polewali Mandar, maka simpulan yang dapat diambil bahwa latihan konsep diri berpengaruh positif dan signifikan terhadap peningkatan kemandirian belajar peserta didik di MAN 1 Polewali Kabupaten Polewali Mandar. Hal tersebut berarti bahwa semakin sering peserta didik latihan konsep diri, maka kemandirian belajar peserta didik tersebut akan semakin meningkat pula. Hal ini terbukti dari skor pencapaian konsep diri peserta didik yang berada dalam kategori sedang, maka hal tersebut diikuti pula dengan skor pencapaian kemandirian belajar peserta didik yang juga berada dalam kategori sedang. Besar korelasinya adalah 0,641 yang berkategori sedang dan nilai signifikansi lebih kecil dari 0,05 yaitu $0,000<0,05$. Kontribusi pengaruh variabel latihan konsep diri terhadap peningkatan kemandirian belajar peserta didik di MAN 1 Polewali Kabupaten Polewali Mandar sebesar 41,1\%, sedangkan sisanya yaitu 58,9\% dipengaruhi oleh faktor lain di luar bahasan penelitian.

\section{B. Saran}

1. Bagi guru, guru disarankan untuk meningkatkan konsep diri peserta didik melalui latihan konsep diri dengan membiasakan peserta didik untuk berani tampil di depan dan melakukan penilaian diri untuk meningkatkan konsep diri peserta didik agar kemandirian belajarnya meningkat.

2. Bagi peserta didik, disarankan untuk melakukan komunikasi yang baik antar sesama teman dan belajar dari kesalahan untuk memperbaiki diri menjadi lebih baik. Juga disarankan agar

\footnotetext{
${ }^{18}$ Elizabeth B. Hurlock, Psikologi Perkembangan Suatu Pendekatan Rentang Kehidupan (Jakarta: Erlangga, 2007), h. 235 .

${ }^{19}$ Slovia Lintina, "Pengaruh Konsep Diri dan Pola Asuh Orang Tua terhadap Kemandirian Mahasiswa Fakultas Psikologi UIN Syarif Hidayatullah Jakarta” (Jakarta: UIN Syarif Hidayatullah Jakarta, 2015), h. 34.
} 
peserta didik sering melakukan latihan konsep diri agar kepercayaan dirinya meningkat dan kemandirian belajarnya juga meningkat.

\section{DAFTAR PUSTAKA}

Amirin, Tatang M. Manajemen Pendidikan. Yogyakarta: UNY Press, 2011.

Arikunto, Suharsimi. Prosedur Penelitian Suatu Pendekatan Praktik. Jakarta: Rineka Cipta, 2013.

Corey, Gerald. Teori dan Praktik Konseling dan Psikotraphy. Bandung: Refika Aditama, 2013.

Coulhoun, JF \& JR. Acocella, Psikologi tentang Penyesuaian dan Hubungan Kemanusiaan, Alih bahasa: Prof. Dr. Ny. R.S Satmoko. Semarang: UNS Press, 2009.

Hatimah, Ihat. Pembelajaran Berwawasan Masyarakat. Jakarta: Universitas Terbuka, 2008.

Hurlock, Elizabeth B. Perkembangan Anak Jilid 2. Jakarta: Erlangga, 2013.

Hurlock, Elizabeth B. Psikologi Perkembangan Suatu Pendekatan Rentang Kehidupan. Jakarta: Erlangga, 2007.

Kurnanto, Edi. Konseling Kelompok. Bandung: Alfabeta, 2013.

Lickona, Thomas. Educating for Character: Mendidik untuk Membentuk Karakter: Bagaimana Sekolah dapat Memberikan Pendidikan tentang Sikap Hormat dan Bertanggung Jawab. Jakarta: Bumi Aksara, 2012.

Lintina, Slovia, Pengaruh Konsep Diri dan Pola Asuh Orang Tua terhadap Kemandirian Mahasiswa Fakultas Psikologi UIN Syarif Hidayatullah Jakarta. Jakarta: UIN Syarif Hidayatullah Jakarta, 2015.

Mujiman, Haris Manajemen Pelatihan Berbasis Belajar Mandiri. Yogyakarta: Pustaka Pelajar, 2013. Nina, Syam W. Psikologi Sosial. Bandung: Remaja Rosdakarya, 2012.

Rusman. Model-model Pembelajaran Mengembangkan Profesional Guru. Jakarta: Rajawali Press, 2011.

Sagala, Syaiful. Konsep dan Makna Pembelajaran. Bandung: Alfabeta, 2010.

Sarastika, Pradipta. Buku Pintar Tampil Percaya Diri. Yogyakarta: ARASKA, 2014.

Siregar, Syofian P. Statistik Deskriptif Untuk Penelitian. Jakarta: Raja Grafindo Persada, 2013.

Sugiyono. Metode Penelitian Pendekatan Kualitatif, Kuantitatif, dan $R \&$ D. Bandung: Alfabeta, 2015.

Sukardi, Dewa Ketut. Bimbingan dan Konseling di Sekolah. Jakarta: Rineka Cipta, 2010.

Sukmadinata, Nana Syaodih. Metode Peneltian Pendidikan. Bandung: Remaja Rosdakarya, 2012.

Sutoyo, Ahmad. Pemahaman Individu. Semarang: Widya Karya, 2009.

Tirtarahardja, Umar dan S. L. La Sulo. Pengantar Pendidikan. Jakarta: Rineka Cipta, 2010.

Yusri. Statistika Sosial: Aplikasi dan Interpretasi. Yogyakarta: Graha Ilmu, 2013. 